\title{
In vitro colonic fermentation of Mexican "taco" from corn-tortilla and black beans in a Simulator of Human Microbial Ecosystem (SHIME ${ }^{\circledR}$ ) system
}

\author{
Alicia Paulina Cárdenas-Castro ${ }^{\mathrm{a}}$, Fernanda Bianchi ${ }^{\mathrm{b}}$, María Angela Tallarico-Adorno ${ }^{\mathrm{c}}$, \\ Efigenia Montalvo-González ${ }^{\mathrm{a}}$, Sonia G. Sáyago-Ayerdi ${ }^{\mathrm{a}, *}$, Katia Sivieri ${ }^{\mathrm{b}, *}$ \\ a Tecnológico Nacional de México/Instituto Tecnológico de Tepic, Av. Tecnológico No 2595, Col. Lagos del Country, CP 63175 Tepic, Nayarit, Mexico \\ ${ }^{\mathrm{b}}$ UNESP-Univ Estadual Paulista, Department of Food and Nutrition, Rodovia Araraquara Jaú/Km $1 \mathrm{~s} / \mathrm{n}, 14800-903$ Araraquara, SP, Brazil \\ ${ }^{c}$ Laboratory of Biological Processes-LPB, School of Engineering of São Carlos-EESC/USP, São Carlos, São Paulo, Brazil
}

\section{A R T I C L E I N F O}

\section{Keywords:}

Tortilla

Beans

Taco

Microbiota

Short chain fatty acids

Ammonium

Fermentation

SHIME

\begin{abstract}
A B S T R A C T
A Mexican staple food prepared with corn "tortilla" (Zea mays L.) and common beans (Phaseolus vulgaris L.) is named as "taco". It was fermented in an in vitro colonic Simulator of Human Microbial Ecosystem (SHIME $\left.{ }^{\circledR}\right)$ to evaluate the effect in short chain fatty acids (SCFA), ammonia production, and the growth of total presumptive counts for anaerobic bacteria, Lactobacillus spp., Bifidobacterium spp., Clostridium spp., and total coliforms in the three simulated reactors of the human colon. After two weeks of stabilization, the simulator was fed during 9 days with the mixture of $50 \mathrm{~g}$ of beans and $50 \mathrm{~g}$ of tortilla mixed with $100 \mathrm{~mL}$ of carbohydrate based medium. Every third day, samples were collected from the three simulated colon vessels for the corresponding analysis. The production of the SCFA was higher during the treatment period than the basal period in the three colon sections. The acetate was produced in higher concentration $(191.9 \mathrm{mmol} / \mathrm{L})$ than propionate and butyrate $(29.1$ and $55.0 \mathrm{mmol}$ ). During the treatment period, the higher molar ratio (\%) for acetate, propionate, and butyrate were 84: 14: 24, respectively. The ammonia ions as well as the growth of presumptive coliforms were reduced $(\mathrm{p}<0.05)$ in the three simulated colon vessels during the treatment. Finally, in vitro fermentation of Mexican "taco" showed a possible potential functional profile of an ancestral staple food due to the production of SCFA that may exert beneficial effects.
\end{abstract}

\section{Introduction}

Mexican foods are worldwide known because of the nutritional importance contribution of its ingredients being the first cuisine of a country accepted in 2010, for the Intergovernmental Committee by the Safeguarding of the Intangible Cultural Heritage of UNESCO (Gálvez \& Salinas, 2015). Recently, studies reported drastic changes in food consumption in Mexico (Flores et al., 2010). In that sense, the intake of native foods has decreased and the intake of high fat diets has increased (Rivera et al., 2002). However, two of the most native foods in the Mexican diet are corn and beans. Even with the changes in Mexican dietary habits the consumption of beans is about $10 \mathrm{~kg}$ per person/per year (Phaseolus vulgaris L.) (Gálvez \& Salinas, 2015) and approximately 95\% of Mexicans consume corn (Zea mays L.) cooked as "tortilla" (flat discs with a diameter from 12 to $18 \mathrm{~cm}$ and from 1 to $4 \mathrm{~mm}$ thick). The consumption of tortilla in Mexico per person/per day is $325 \mathrm{~g}$ (RojasMolina et al., 2007), and supplies $70 \%$ and $50 \%$ of the daily-consumed calories and the daily-consumed protein, respectively (Sáyago-Ayerdi,
Tovar, Osorio-Díaz, Paredes-López, \& Bello-Pérez, 2005). Besides, the content of protein in beans is about $20-25 \%$, where $40-50 \%$ is represented by the protein phaseolin and $10-27 \%$ is represented by lectins (Carrasco-Castilla et al., 2012). Its high relative resistance to proteolysis but the cooked processes improves digestibility of phaseolin (Yin, Tang, Wen, Yang, \& Yuan, 2010). Even $\alpha$-amylase inhibitor ( $\alpha$ $\mathrm{AL}$ ), arcelin, and phytohemagglutinin (PHA) reduce protein digestibility, these members of the protein profile in beans could also exert anticarcinogenic effects (González de Mejía, Valadez-Vega, ReynosoCamacho, \& Loarca-Piña, 2005). Also, common beans contain micronutrients as well as, bioactive compounds distributed in the different anatomic parts of the bean seed. In this sense, the pericarp contents dietary fiber (DF), minerals, and phenolic compounds (PC), specifically anthocyanins in black beans: delphinidin, petunidin, malvidin and pelargonidin (Chávez-Mendoza \& Sánchez, 2017). Starch, resistant starch (RS), and DF are the major constituents of carbohydrates present in corn tortilla and beans. It has been reported that the content of soluble dietary fiber (SDF), insoluble dietary fiber (IDF) and total dietary fiber

\footnotetext{
* Corresponding authors.

E-mail addresses: ssayago@ittepic.edu.mx (S.G. Sáyago-Ayerdi), sivierik@fcfar.unesp.br (K. Sivieri).
} 
(TDF) in black beans was 5.6, 25.5 and 31.2\% (Silva-Cristobal, OsorioDíaz, Tovar, \& Bello-Pérez, 2010), respectively, and in tortilla was 2.4, 10.5 and 12.9\% (Bello-Pérez et al., 2014), respectively. Besides, the indigestible fraction (IF) is a physiological concept that comprises most components of vegetable foods that escape digestion and absorption in the small intestine, reaching the colon where they are susceptible to bacterial fermentation, e.g. TDF (Saura-Calixto, García-Alonso, Goni, \& Bravo, 2000).

The mixture of bean and corn tortilla is called "taco" and it is traditionally consumed in Mexico. The "Taco" has important quantities of DF. The content of SDF, IDF, TDF in bean-corn flour was $2.3 \%, 10.4 \%$ and $12.76 \%$ (Treviño-Mejía, Luna-Vital, Gaytán-Martínez, Mendoza, \& Loarca-Piña, 2016), respectively, and it has been reported a content of RS of 3.9\% (Sáyago-Ayerdi, Tovar, Osorio-Díaz, Paredes-López, \& BelloPérez, 2005) in "taco", which resist human gastrointestinal digestion conditions and reach the colon (Silva-Cristobal, Osorio-Díaz, Tovar, \& Bello-Pérez, 2010). In that sense, several studies reported that the main products of the fermentation of RS are the short chain fatty acids (SCFA) (Ahmed, Segal, \& Hassan, 2000; Henningsson, Nyman, \& Bjork, 2002; Nugent, 2005; Topping, 2007) as butyrate, propionate and acetate whose may exert benefits to the colon health (Hamer et al., 2008; Haralampu, 2000; Huda-Faujan et al., 2010; Scheppach, Bartram, \& Richter, 1995).

The gastrointestinal (GI) human digestion has been a scientific approach, hence, several GI in vitro systems has been designed due to in vivo studies have limitations (ethical policies, high experimental costs and difficulty in sampling from the gut) (Sáyago-Ayerdi, Zamora-Gasga, \& Venema, 2017). Thus, the static models are the most representative digestive systems, but these models do not reproduce the multiple changes along the process in $\mathrm{pH}$ and secretion flow rated and even dynamic models do, i.e., the Dynamic Gastric Model (DGM) only simulates a partial process of GI digestion (the stomach) (Guerra et al., 2012). A dynamic in vitro system that integrates the whole GI tract from stomach to colon is the Simulator of Human Microbial Ecosystem, SHIME $^{\circledR}$, that has a proven system to study aspects of human intestinal microbiota during food fermentation (De Boever, Deplancke, \& Verstraete, 2000; Van De Wiele, Boon, Possemiers, \& Verstraete, 2004). It consists of five double-jacketed vessels that simulate the environmental conditions of $\mathrm{pH}$, residence time, inoculum, and temperature of the stomach, the small intestine and the ascending, transverse, and descending colon with a total retention time of $72 \mathrm{~h}$ (Molly, Woestyne, \& Verstraete, 1993; Sivieri et al., 2014). The focus in the use of the SHIME $^{\circledast}$ system has been to evaluate the prebiotic effect of the DF, i.e., fructooligosaccharides (FOS) (Daguet, Pinheiro, Verhelst, Possemiers, \& Marzorati, 2016) and to evaluate the probiotic effect of Lactobacillus (Barroso et al., 2014) but, as far as we know, the SHIME ${ }^{\circledR}$ system has not been used to evaluate the effects of the fermentation of a more complex food matrix. Besides, the profile of microbial metabolites produced is strongly determined by the compounds of the food matrix that would reach the colon (Flint, Duncan, Scott, \& Louis, 2015). Thus, the aim of this study was to evaluate the effect in short chain fatty acids (SCFA) production, ammonia production and the growth of certain presumptive bacterial groups during the in vitro colonic fermentation of Mexican "taco" in the SHIME ${ }^{\circledR}$ reactor system.

\section{Materials and methods}

\subsection{Preparation of the Mexican "taco"}

Corn "tortillas" were bought in a local supermarket in Tepic, Nayarit, Mexico. 'Negro Jamapa' variety of common beans was donated (Cadena Agroalimentaria de Frijol de Nayarit). They were washed with tap water and cooked to controlled pressure until the same degree of tenderness of each bean was obtained. Mexican "taco" was made under the $5: 5$ bean-tortilla proportions because it was the properly proportion according to the general experimental protocol (Molly, Woestyne, Smet,
Table 1

Phenolic compounds (PC), resistant starch (RS) and total indigestible fraction (TIF) content of the Mexican "taco", 5:5 bean-tortilla proportion $(\mathrm{g} / 100 \mathrm{~g} \mathrm{DW})^{\mathrm{a}}$.

\begin{tabular}{ll}
\hline Parameter & Mexican "taco" \\
\hline PC $^{\mathrm{b}}$ & $3.70 \pm 0.37$ \\
RS & $4.65 \pm 0.04$ \\
Indigestible fraction (IF) content & \\
$\quad$ Soluble IF & $2.98 \pm 0.33$ \\
Insoluble IF & $28.98 \pm 1.80$ \\
Total IF & $31.11 \pm 2.28$ \\
\hline
\end{tabular}

a Data are means of three repetitions \pm standard deviation $(n=3)$; Dry weight (DW).

b mg GAE/g DW. Gallic acid equivalentes (GAE).

c Total IF $=$ Sum of soluble IF + insoluble IF.

\& Verstraete, 1994). The content of RS was measured as the non-hydrolyzed enzymatic starch fraction in the small intestine (Goñi, GarciaDiz, Mañas, \& Saura-Calixto, 1996). The total indigestible fraction (TIF) (Saura-Calixto, García-Alonso, Goni, \& Bravo, 2000) was evaluated this protocol simulates the physiological conditions of human digestion. The PC were evaluated in supernatants from a previous organic aqueous extraction (Pérez-Jiménez et al., 2008) using a microplate reader (Biotek ${ }^{\circledast}$ Synergy HT, USA). The absorbance was read at $750 \mathrm{~nm}$ (Montreau, 1972) modified from Alvarez-Parrilla, de la Rosa, Amarowicz, and Sahidi (2010). The composition in RS, TIF and PC of the studied "taco" is shown in the Table 1.

\subsection{Dynamic SHIME ${ }^{\circledR}$ model}

Briefly, the SHIME system, developed at Ghent University, is a dynamic model of the human gastrointestinal tract. The vessels of the SHIME $^{\circledR}$ system operated at $37^{\circ} \mathrm{C}$ and were stirred continuously using a magnetic stirrer. The inside of each vessel was kept in anaerobiosis through the daily injection of $\mathrm{N}_{2}$ for $30 \mathrm{~min}$, and the $\mathrm{pH}$ of each portion of the tract was automatically adjusted with the addition of $0.5 \mathrm{~N} \mathrm{NaOH}$ or $0.5 \mathrm{~N} \mathrm{HCl}$ (Molly, Woestyne, Smet, \& Verstraete, 1994; Possemiers, Verthé, Uyttendaele, \& Verstraete, 2004). Stomach conditions were simulated in reactor one, at $\mathrm{pH} 2$ with pepsin from porcine gastric mucosa (Sigma, P6887) at a concentration of $1 \mathrm{~g} / \mathrm{L}$, under micro-aerophilic conditions for $2 \mathrm{~h}$, at $37{ }^{\circ} \mathrm{C}$ (Possemiers, Marzorati, Verstraete, \& Van de Wiele, 2010). The passage of food in the small intestine was simulated in reactor two by the addition of $60 \mathrm{~mL}$ artificial pancreatic and bile liquid [6 $\mathrm{g} / \mathrm{L}$ oxgall (Sigma, Brazil), $1.9 \mathrm{~g} / \mathrm{L}$ pancreatin from porcine pancreas (Sigma, P1750) and 12.5 g/L NaHCO 3 ], pH 6.5-7.5 (Molly, Woestyne, Smet, \& Verstraete, 1994; Possemiers, Verthé, Uyttendaele, \& Verstraete, 2004). Colonic fermentation were simulated in reactor three (ascendant colon-AC), four (descendent colon-DC) and five (transverse colon-TC), at the beginning of the experiments, the colonic reactors were inoculated with non-gas producing (methane $<3 \mathrm{ppm}$ ) stool samples from three adult volunteers who declared did not taken antibiotics in the two years prior. As the production of methane gas is directly related to an increase of acetic acid and consequently, the increase in total SCFA (Wolever, Robb, Ter Wal, \& Spadafora, 1993), the volunteers classified as methane producers were excluded. For this classification, the breath methane dosage of four lean volunteers was performed through a Quintron digital Breathtracker Microlyzer at the Pedriatric Gastroenterology Department of the São Paulo Federal School. The stool inoculum was prepared using the method described by Possemiers, Marzorati, Verstraete, and Van de Wiele (2010)). The microbial inoculum was stabilized for two weeks (basal period) on a carbohydrate-based medium [( $3 \mathrm{~g} / \mathrm{L}$ of starch (Unilever, Brazil), $2 \mathrm{~g} / \mathrm{L}$ of pectin (Sigma, USA), $4 \mathrm{~g} / \mathrm{L}$ of type III mucin from porcine stomach (Sigma, USA), $1 \mathrm{~g} / \mathrm{L}$ of xylan (Sigma, USA), $1 \mathrm{~g} / \mathrm{L}$ of peptone (Acumedia, USA), $1 \mathrm{~g} /$ Lof arabinogalactan (Sigma, USA), $0.4 \mathrm{~g} / \mathrm{L}$ of glucose 


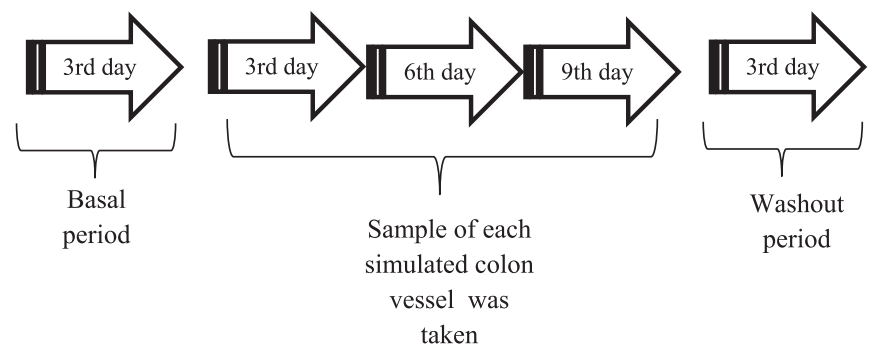

Fig. 1. Experimental setup of SHIME ${ }^{\circledR}$ during "taco" fermentation. Basal period after two weeks of stabilization (system fed only the carbohydrate-based medium). Sample of each simulated colon vessel in the SHIME ${ }^{\circledR}$ system during 9 days (every 3rd day was taken sample for the corresponding analysis). The washout period last 3 days and the system was submitted under the same conditions of the basal period.

(Synth,Brazil), $3 \mathrm{~g} / \mathrm{L}$ of yeast extract (Acumedia, USA), and $0.5 \mathrm{~g} / \mathrm{L}$ of Lcysteine (Sigma, USA). Three times per day, the liquid feed was entered to the system (Payne et al., 2003; Possemiers, Verthé, Uyttendaele, \& Verstraete, 2004) to adapt the microorganisms to the specific environmental conditions $\mathrm{pH}$ range, retention time and available carbon sources) of the three sections of human colon (Possemiers, Verthé, Uyttendaele, \& Verstraete, 2004). After two weeks of stabilization (basal period), the reactor was fed during 9 days (every 3rd day was taken sample for the corresponding analysis) with the mixture of $50 \mathrm{~g}$ of cooked beans and $50 \mathrm{~g}$ of tortilla mixed with $100 \mathrm{~mL}$ of carbohydrate-based medium and ground in a blender to obtain a homogeneous particle. The mixture of the "taco" with the carbohydrate-based medium produced a semisolid mixture that simulated the physicochemical characteristics of the "chemo". During washout period, that lasted 3 days, only the carbohydrate-based medium was added to the system ( $100 \mathrm{~mL}$ three times a day). The experimental setup of SHIME ${ }^{\circledR}$ during "taco" fermentation is shown in Fig. 1.

\subsection{Microbiological analysis}

\subsubsection{Analysis of microbiota composition}

The intestinal microbiota composition analysis was based on the enumeration of total presumptive counts for the anaerobic bacteria, Lactobacillus spp., Bifidobacterium spp., Clostridium spp., and total coliforms. Total presumptive anaerobic bacteria amounts were determined by plating on Standard Methods Agar (Himedia, Brazil) and anaerobic incubation (Anaerogen Anaerobic System, Probac do Brazil) at $37^{\circ} \mathrm{C} /$ $48 \mathrm{~h}$. Agar MRS (Himedia, Brazil) was used to determine the population of presumptive lactobacilli. BIM-25 agar with anaerobic incubation at $37^{\circ} \mathrm{C} / 72 \mathrm{~h}$ was used to determine the population of presumptive Bifidobacterium spp. (Sanguinetti, Dias, \& Simpson, 1994). Presumptive Clostridium spp. (Munoa \& Pares, 1988) was enumerated anaerobically by using Reinforced Clostridial Agar at $37^{\circ} \mathrm{C} / 48 \mathrm{~h}$. Petrifilm ${ }^{\mathrm{TM}}$ EC ( $\left.3 \mathrm{M}\right)$ with anaerobic incubation at $37^{\circ} \mathrm{C} / 48 \mathrm{~h}$ was used to determine the population of total presumptive coliforms. For sampling purposes, $1 \mathrm{~mL}$ of a sample taken from each reactor was suspended in $9 \mathrm{~mL}$ of peptone water. Serial dilutions were prepared and inoculated into the selective culture media. The plate counts analysis was performed in triplicate.

\subsection{Ammonium analysis in digested sample}

The ammonia content was determined at $25^{\circ} \mathrm{C}$ using a selective ion meter (710A model, Orion) coupled to an ammonia selective-ion electrode (Orion 95-12). This equipment was calibrated using $0.1 \mathrm{M}$ standard ammonium chloride solutions. It was added to every $25 \mathrm{~mL}$ of sample took once a week from the simulated colon vessels, throughout the three experimental periods (basal, treatment and washout), $0.5 \mathrm{~mL}$ ionic strength adjuster (ISA, Orion) solution, a pH-adjusting and ionic force solution (Bedani, 2008). The analysis was performed in triplicate.

\subsection{Analysis of short-chain fatty acids (SCFA')}

The SCFA were extracted from the samples with diethyl ether, after the addition of 2-methyl hexanoic acid as an internal standard. The SCFA were quantified using a gas chromatograph equipped with a flame-ionization gas detector, a capillary split/spitless injector and an HP-INNOWAX column with a $30 \mathrm{~m} \times 0.25 \mathrm{~mm} \times 0.25 \mu \mathrm{m}$ inlet (Shidmadzu GC2010) with a flow rate of $1.56 \mathrm{~mL} / \mathrm{min}$ of hydrogen as the carrier. The temperatures of the column, injector and detector were 170,150 and $280^{\circ} \mathrm{C}$, respectively (Van De Wiele, Boon, Possemiers, Jacobs, \& Verstraete, 2007). The analyses were made in triplicate and the samples were collected according to the experimental set up (Fig. 1) from the vessels were frozen at $-20^{\circ} \mathrm{C}$.

\subsection{Statistical analysis}

Data of all the analysis are means of three replicates. Significance of all results was evaluated using the statistical software STASTICA, version 10 (Statsoft. 1984-2011 Inc., Tulsa, OK, U.S.A.) with one-way ANOVA, and individual means were compared using the Tukey's test $(\mathrm{p}<0.05)$.

\section{Results and discussion}

\subsection{Microbial qualitative changes during "taco" passage through the SHIME ${ }^{\circledR}$ reactor}

The changes in intestinal presumptive microbiota during the fermentation of "taco" are shown in Fig. 2. Presumptive counts of total coliforms growth decreased in all the three colon vessels (AC, TC and DC) in the first 3 days of treatment; almost $3 \log$ CFU decrease was observed in the AC. Indeed, in the same period time as presumptive counts of total coliforms, presumptive counts of total anaerobes decreased $2 \log$ CFU in the TC, $1 \log$ CFU in DC and almost $1 \log$ CFU in the AC. In the 6th of treatment, 2 log CFU decreased in presumptive counts of Clostridium spp. was found in the simulated TC but in the 9th day of treatment, until $1 \log \mathrm{CFU}$ increase was observed in all the three colon vessels. Non-significant differences $(p>0.05$ ) were observed during the washout period in the AC and TC.

Presumptive counts of Lactobacillus spp. during the treatment was decreased until $2 \log \mathrm{CFU}$ in all the colon three vessels. Nevertheless, during the washout period $1 \log \mathrm{CFU}$ increase was observed in the AC. In the other hand, after 3 days of treatment, almost 1 log CFU increase in presumptive counts of Bifidobacterium spp. population was observed in the simulated AC. But, at 6th day of treatment, 2 log CFU decrease was observed in all the three colon sections. In the simulated DC was observed $1 \log$ CFU decrease $(\mathrm{p}<0.05)$ during the washout period.

The main behavior of the growth of the presumptive microorganisms during the fermentation of this staple food was the decreased in the different colon sections, and this behavior was particularly observed for the presumptive counts of Clostridium spp. and coliforms. Nevertheless, it is important to take into account that during the fermentation of an IF of a complex food matrix could exist different interactions that limit the availability or bioaccessibility of substrates. Chemical interactions between the food complex matrix (e.g. covalent bonds) or the formation of complex among protein-carbohydrates fermented could limited the bioaccessibility of certain nutrients (substrates) to the gut microbiota that may influenced the variations in the microbial groups growth (Jakobek, 2015). The selective effects of any substrate may suggest that species that become more dominant during treatment express metabolic routes for its degradation or they are more resistant to these compounds (Jin \& Hattori, 2012). Hence, it would be more difficult for the gut microbiota to access or metabolize the fermentable components of a complex food matrix that reach the colon. This could explain the reliability growth of the presumptive microbial groups measured in this study. The presumptive Lactobacilli population 

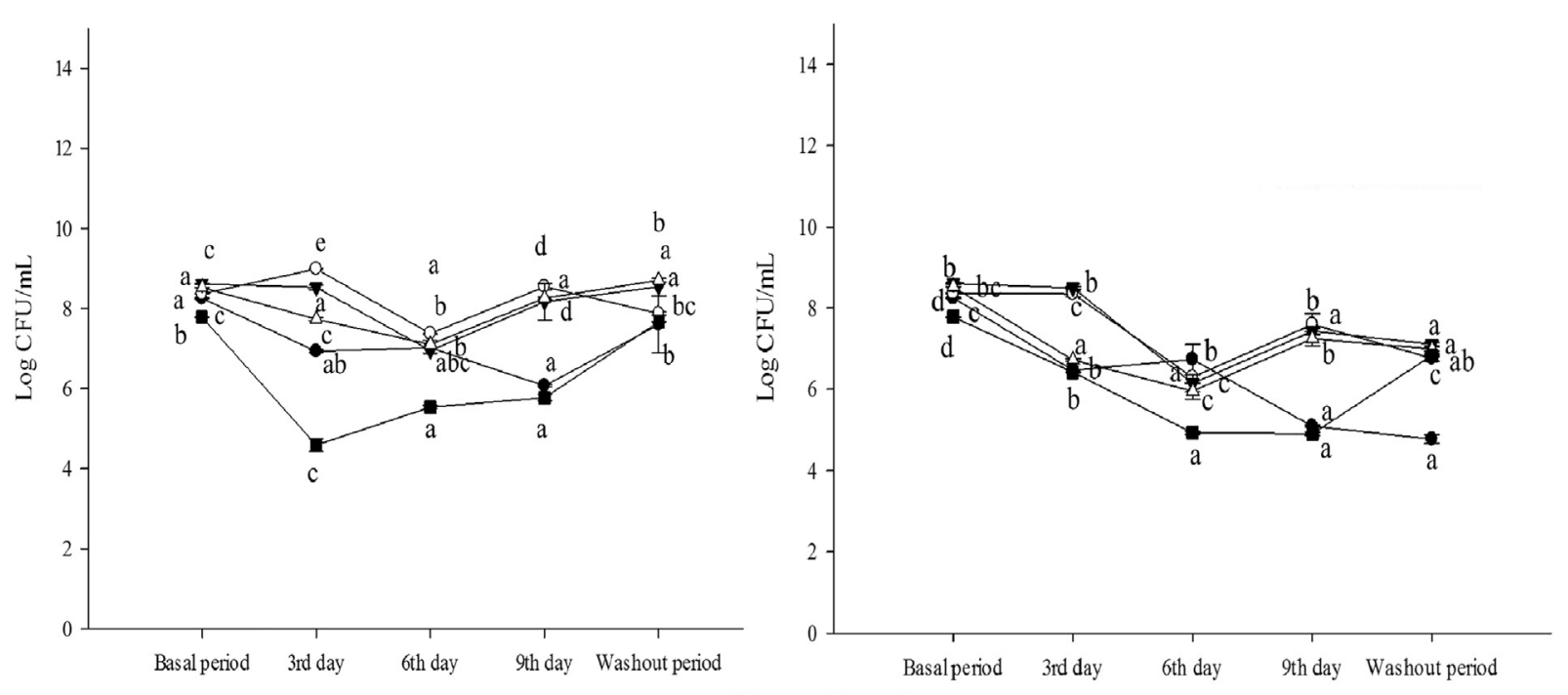

Descending colon

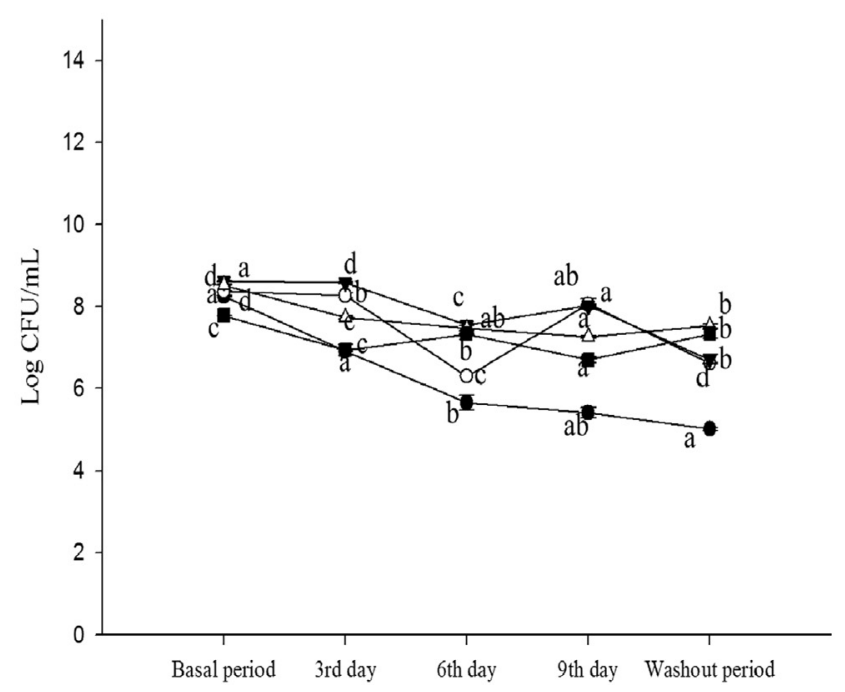

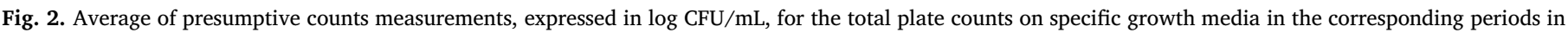

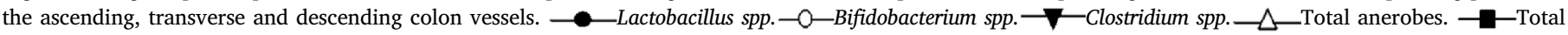

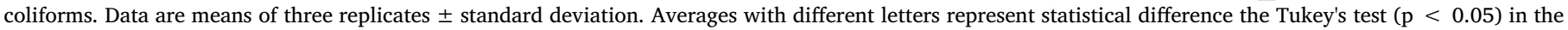
same microbial group.

Table 2

Ammonium ion production (ppm) in SHIME $^{\circledR}$ run during the treatment ${ }^{1}$.

\begin{tabular}{llll}
\hline & Ascending colon & Transverse colon & Descending colon \\
\hline Basal period & $431.66 \pm 1.52^{\mathrm{d}}$ & $512.33 \pm 12.01^{\mathrm{d}}$ & $577.33 \pm 21.93^{\mathrm{d}}$ \\
3rd day & $53.16 \pm 3.78^{\mathrm{a}}$ & $121.00 \pm 3.60^{\mathrm{b}}$ & $200.66 \pm 12.74^{\mathrm{a}}$ \\
6th day & $36.76 \pm 2.10^{\mathrm{b}}$ & $149.00 \pm 1.00^{\mathrm{a}}$ & $212.00 \pm 3.60^{\mathrm{a}}$ \\
9th day & $49.56 \pm 3.82^{\mathrm{a}}$ & $155.00 \pm 2.00^{\mathrm{a}}$ & $267.00 \pm 14.73^{\mathrm{b}}$ \\
Washout period & $411.00 \pm 8.54^{\mathrm{c}}$ & $490.00 \pm 5.00^{\mathrm{c}}$ & $525.00 \pm 4.32^{\mathrm{c}}$ \\
\hline
\end{tabular}

Different uppercase letters in the same column represent statistical difference to the Tukey's test $(p<0.05)$.

1 Data are means of three replicates \pm standard deviation $(n=3)$.

as well as, certain species of presumptive Bifidobacteria population or presumptive Clostridium spp. could not express metabolic routes for degradation of PC and other substrates available during the treatment. The effect of dietary polyphenols on the microbiota community due to the microbial breakdown products whose may increase or decrease the growth of bacterial populations in the human intestine (Lee, Jenner, Low, \& Lee, 2006). For example, black tea polyphenols and red wine/ grape juice (RWGE) polyphenols were fermented in the SHIME $^{\circledR}$ system showing that both polyphenols sources evaluated stimulated Klebsiella, and Akkermansia and reduced Bifidobacteria, B. coccoides and Anaeroglobus but particularly, black tea polyphenols reduced Victivallis and RWGE promoted growth of Alistipes, Cloacibacillus, Victivalli but Subdoligranulum and Bacteroides were decreased (Kemperman et al., 2013). Then, PC could exert antibacterial properties (Kemperman, Bolca, Roger, \& Vaughan, 2010), which could be attributed to the decrease of presumptive anaerobes and total coliforms.

In addition, the gut microbiota in the intestinal metabolism can modulate the effects that PC and other fermentable compound may exert in human health due to the modification in absorption, bioavailability and biologic activity of those, outstanding, the biological effects could not be just attribute to the native compound in food, also to their metabolites (Duda-Chodak, Tarko, Satora, \& Sroka, 2015).

\subsection{Ammonium ion production}

A significant reduction $(\mathrm{p}<0.05)$ in ammonium ions production in AC, TC and DC (Table 2) colon sections was observed during the treatment. At the first 3 days, an $86.8,76.2$ and $64.3 \%$ reduction ( $\mathrm{p}<0.05$ ) was observed in AC, TC, and DC vessels, respectively. In the 
6th day of treatment, a 91\% reduction ( $p<0.05$ ) was observed in the simulated AC, being the higher inhibition percentage in the three vessels. During the washout period an increase $(\mathrm{p}<0.05)$ was observed in all the simulated colon vessels. Ammonia is a key product of metabolic pathways in many organisms, encountered frequently at the crossroads of catabolism and anabolism and their production may be the result of total digestion of tissues proteins by less specific microbial proteinases (Kleiner, Traglauer, \& Domm, 1998). Frequently, the reason for this toxicity may be a consequence of the molecules ability to protonate and deprotonate rapidly, forming molecular species with very different lipophilic charges (Kleiner, Traglauer, \& Domm, 1998). Hence, the decrease during the treatment in ammonium ion production was a positive result because high concentrations of this metabolic product could act as a tumor cancer promotor in colon (Hughes, Magee, \& Bingham, 2000; Scott, Gratz, Sheridan, Flint, \& Duncan, 2013). Since 1942 , it has been reported that decrease in ammonium ion production is a consequence of the fermentation of carbohydrate in cultures because of glucose ability to inhibit synthesis of alanine and glutamate deaminases and aspartase attributed to low $\mathrm{pH}$ because of the production of certain acids (nowadays, SCFA's) (Epps \& Gale, 1942). It has been reported that the ammonium concentration in the intestinal lumen increases progressively from the ascending colon to the descending colon due to the higher rate of protein fermentation in the descending colon relative to the ascending colon (Macfarlane, Gibson, \& Cummings, 1992). Then, the lower ammonium production in the ascending colon is attributed to low $\mathrm{pH}$ and high availability of carbohydrates in this region (Smith \& Macfarlane, 1998).

\subsection{Analysis of short chain fatty acids (SCFA)}

The concentration (mmol/L) of SCFA produced is shown in the Table 3. The production of acetate was among 120.83 to $191.99 \mathrm{mmol} /$ $\mathrm{L}$ during the fermentation, non-significant differences $(\mathrm{p}>0.05)$ in propionate and butyrate production were observed. Acetate is the most abundant SCFA in the colon and it represents more than the 50\% of the total SCFA detected in human feces (Louis, Scott, Duncan, \& Flint, 2007). The production of acetate can be due to the content RS and DF of the "taco". In the other hand, the producers species of propionate and butyrate could not grew selectively during the treatment in this study because SCFA production may be influence by the number and species of microorganisms present in the colon, as well as, the substrate available (Macfarlane \& Macfarlane, 2003), e.g., Coprococcus species such as Faecalibacterium prausnitzii within the Ruminococcaceae (clostridial cluster IV) and Eubacterium rectale within the Lachnospiraceae (clostridial cluster XIVa) are producers of butyrate (Geirnaert et al., 2014). Polysaccharides extracted from cooked black bean seeds have been fermented in a static system and the concentration of acetate $(39-51 \mathrm{mmol} / \mathrm{L})$, propionate $(8-12 \mathrm{mmol} / \mathrm{L})$, and butyrate (8-15 mmol/L) were evaluated (Campos-Vega et al., 2009). The maximum amount of acetate, propionate and butyrate production during the fermentation of Mexican "taco" in this study was 191.9, 31.2, and $74.1 \mathrm{mmol} / \mathrm{L}$, respectively. Zamora-Gasga et al., 2018 reported the production of SCFA in traditional Mexican corn "tortilla" fermented in a static in vitro digestion system. After $48 \mathrm{~h}$ of fermentation, the production of acetate, propionate and butyrate was 498, 293.75 and $331.96 \mathrm{mmol} / \mathrm{L}$ per $100 \mathrm{mg}$ of traditional Mexican corn "tortilla" fermented. Nevertheless, the calculation of the molar ratio for acetate, propionate and butyrate (A:P:B molar ratio) would let us to analyze if the abundance expressed in percentage (\%), of SCFA during the treatment was higher or lower than the basal period and washout period and if it was higher or lower compare with other fermented foods. The molar ratio for acetate, propionate and butyrate (A:P:B ratio) calculated with the average production of SCFA during the basal period with Mexican "taco" and the washout period in each simulated colon vessel is shown in the Fig. 3.

In order to compare the molar ratio proportions for SCFA during the fermentation of the Mexican "taco" with another important sources of polysaccharides fermented in the SHIME ${ }^{\circledR}$ system, it was analyzed the molar ratio for SFCA during FOS and orange juice fermentation. In the simulated TC the molar ratio for butyrate in the 6th day of fermentation of Mexican "taco" was $24.0 \%$ while the molar ratio during FOS fermentation was $12.3 \%$. In the $\mathrm{AC}$ and $\mathrm{DC}$, the molar ratio for propionate in the 9th day of the treatment with Mexican "taco" was 8.75 and $14.78 \%$, respectively, and compared with the molar ratio of FOS was 2.9 and $13.4 \%$, respectively (Sivieri et al., 2014) using the same system. Besides, in the same simulated regions mentioned, AC and DC, the molar ratio for acetate during the treatment with Mexican "taco" was 84.3 and $75.3 \%$ during the 6th and 3rd day of fermentation, respectively, compared with the 66.4 and $64.5 \%$ molar ratio for acetate during FOS fermentation (Sivieri et al., 2014). However, the molar ratio for butyrate in the 3rd day of the treatment with Mexican "taco" was $21.4 \%$ in the simulated AC, while during the fermentation of fresh

Table 3

Short-chain fatty acid (SFCA) concentration (mmol/L) from the ascending colon (AC), transverse colon (TC), and descending colon (DC) vessels as a result of the treatment with the Mexican "taco"".

\begin{tabular}{|c|c|c|c|c|}
\hline SCFA & Experimental period & AC & TC & DC \\
\hline \multirow[t]{5}{*}{ Acetate } & Basal period & $38.72 \pm 14.89^{b}$ & $43.25 \pm 4.92^{\mathrm{a}}$ & $35.15 \pm 3.01^{c}$ \\
\hline & 3rd day & $191.99 \pm 23.00^{\mathrm{a}}$ & $168.23 \pm 3.67^{c}$ & $164.59 \pm 5.75^{\mathrm{a}}$ \\
\hline & 6th day & $142.13 \pm 9.15^{\mathrm{a}}$ & $150.25 \pm 14.46^{\mathrm{bc}}$ & $160.95 \pm 1.48^{\mathrm{a}}$ \\
\hline & 9th day & $149.16 \pm 15.19^{\mathrm{a}}$ & $120.83 \pm 3.29^{b}$ & $129.10 \pm 18.44^{\mathrm{ab}}$ \\
\hline & Washout period & $49.77 \pm 16.37^{b}$ & $61.69 \pm 9.51^{\mathrm{a}}$ & $106.44 \pm 10.87^{b}$ \\
\hline \multirow[t]{5}{*}{ Propionate } & Basal period & $7.35 \pm 0.19^{\mathrm{a}}$ & $9.99 \pm 2.70^{\mathrm{a}}$ & $9.56 \pm 0.05^{\mathrm{a}}$ \\
\hline & 3rd day & $5.27 \pm 0.73^{\mathrm{a}}$ & $31.24 \pm 12.01^{\mathrm{a}}$ & $21.88 \pm 2.28^{\mathrm{a}}$ \\
\hline & 6th day & $4.92 \pm 2.27^{\mathrm{a}}$ & $23.73 \pm 3.02^{\mathrm{a}}$ & $24.06 \pm 0.40^{\mathrm{a}}$ \\
\hline & 9th day & $17.92 \pm 8.27^{\mathrm{a}}$ & $18.49 \pm 0.41^{\mathrm{a}}$ & $29.14 \pm 9.76^{\mathrm{a}}$ \\
\hline & Washout period & $10.44 \pm 3.55^{\mathrm{a}}$ & $16.60 \pm 6.48^{\mathrm{a}}$ & $29.29 \pm 10.91^{\mathrm{a}}$ \\
\hline \multirow[t]{5}{*}{ Butyrate } & Basal period & $10.27 \pm 1.60^{\mathrm{a}}$ & $15.21 \pm 6.14^{\mathrm{a}}$ & $17.04 \pm 2.78^{\mathrm{a}}$ \\
\hline & 3rd day & $53.83 \pm 9.57^{b}$ & $74.19 \pm 44.88^{\mathrm{a}}$ & $32.03 \pm 6.05^{\mathrm{a}}$ \\
\hline & 6th day & $21.36 \pm 9.72^{\mathrm{a}}$ & $55.03 \pm 4.74^{\mathrm{a}}$ & $40.81 \pm 2.00^{\mathrm{a}}$ \\
\hline & 9th day & $37.62 \pm 6.52^{\mathrm{ab}}$ & $37.08 \pm 2.49^{\mathrm{a}}$ & $69.42 \pm 41.89^{\mathrm{a}}$ \\
\hline & Washout period & $16.44 \pm 8.52^{\mathrm{a}}$ & $34.21 \pm 21.35^{\mathrm{a}}$ & $60.05 \pm 34.23^{\mathrm{a}}$ \\
\hline \multirow[t]{5}{*}{ Total SCFA } & Basal period & $56.35 \pm 13.09^{\mathrm{a}}$ & $68.45 \pm 13.78^{\mathrm{a}}$ & $61.75 \pm 0.16^{\mathrm{b}}$ \\
\hline & 3rd day & $251.11 \pm 12.68^{\mathrm{c}}$ & $273.67 \pm 53.21^{b}$ & $218.49 \pm 2.58^{\mathrm{a}}$ \\
\hline & 6th day & $168.42 \pm 21.16^{\mathrm{b}}$ & $229.01 \pm 22.23^{b}$ & $225.83 \pm 0.11^{\mathrm{a}}$ \\
\hline & 9th day & $204.71 \pm 29.98^{\mathrm{bc}}$ & $176.41 \pm 0.39^{\mathrm{ab}}$ & $227.67 \pm 13.68^{\mathrm{a}}$ \\
\hline & Washout period & $76.66 \pm 4.30^{\mathrm{a}}$ & $112.51 \pm 18.32^{\mathrm{a}}$ & $195.79 \pm 34.27^{\mathrm{a}}$ \\
\hline
\end{tabular}

Different uppercase letters in the same column represent statistical difference to the Tukey's test (p $<0.05)$.

1 Data are means of three replicates \pm standard deviation $(n=3)$. 
Acetate

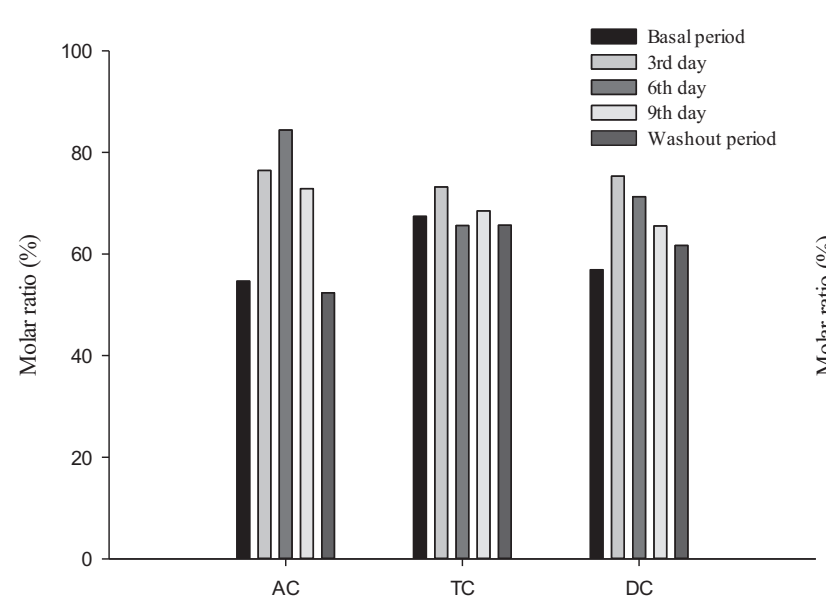

Propionate

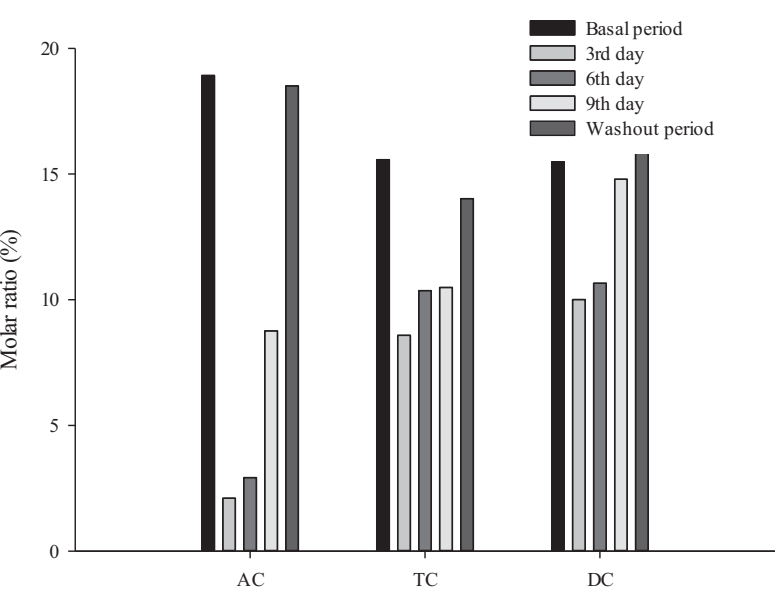

Butyrate

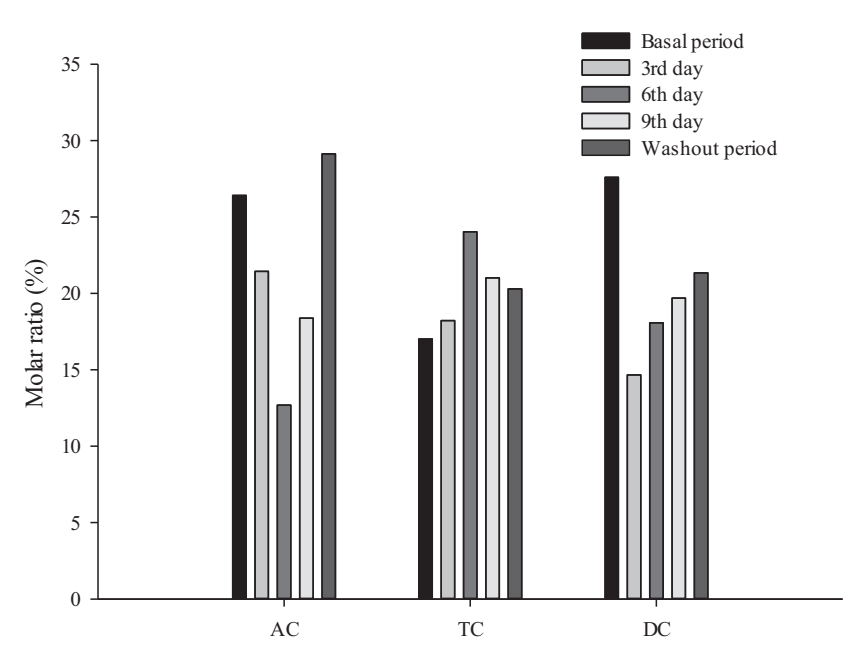

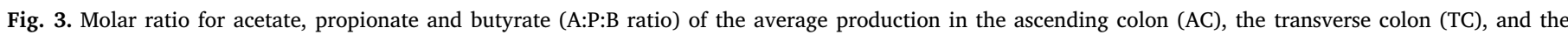
descending colon (DC) vessel of the SHIME ${ }^{\circledR}$ system as a result of the treatment with the Mexican "taco".

orange juice was $11.8 \%$ in the same simulated colon vessel (Duque, Monteiro, Adorno, Sakamoto, \& Sivieri, 2016). Moreover, the maximum molar ratio of acetate during the fermentation of chitin-glucan in a TWINSHIME ${ }^{\circledR}$ reactor system was 53\% and among $14-24 \%$ for butyrate (Marzorati, Maquet, \& Possemiers, 2017). The molar ratio for acetate was higher during the treatment with Mexican "taco" (84.3\%) than the molar ratio of acetate during the fermentation of chitin-glucan while the molar ratio for butyrate during the fermentation of Mexican "taco" was the same value reported during the chitin-glucan fermentation. The molar ratio for the production of propionate and butyrate by the microbiota after $48 \mathrm{~h}$ of traditional Mexican corn "tortilla" fermentation was $26.14 \%$ and $29.54 \%$, respectively (Zamora-Gasga et al., 2018). This molar ratio is higher than the molar ratio for the production of propionate and butyrate by the microbiota $(14.78 \%$ in the DC and $24 \%$ in the TC, respectively) during the fermentation of Mexican "taco" in the SHIME $^{\circledR}$ system but the molar ratio for acetate during the treatment with Mexican "taco" was higher ( $84.3 \%$ in the AC) than the molar ratio for the production of acetate by the microbiota was higher during the treatment in traditional Mexican corn "tortilla" (51.23\%). Even an increase in acetate, propionate and butyrate production was not observed during the "taco" fermentation, the molar ratio for acetate was higher compared to the molar ratio for acetate during other polysaccharides fermentation. Thus, the Mexican "taco" could be an enriched substrate for the microbiota for the production of acetate.

\section{Conclusions}

Mexican "taco" showed a possible potential functional profile of an ancestral staple food due to the production of SCFA and the decrease in ammonium ion concentrations during its fermentation. In order to improve our knowledge of the effects in gut microbiota metabolism of the colonic fermentation of cooked food (even the preparation method could influence during the fermentation) as eaten (mixturing protein, carbohydrates, fiber, bioactive compounds) and the possible effects in host health of gut metabolites, combination of in vitro and in vivo studies are needed.

\section{Acknowledgements}

The study was conducted by the agreement of Tepic Technological Institute (ITTepic) and UNESP-Universidade Estadual Paulista, School of Pharmaceutics Sciences, campus Araraquara. Cárdenas-Castro AP acknowledge and financial support to CONACYT, Mexico for a grant (Registration number: 662703).

\section{References}

Ahmed, R., Segal, I., \& Hassan, H. (2000). Fermentation of dietary starch in humans. The American Journal of Gastroenterology, 95, 1017-1020. 
Alvarez-Parrilla, E., de la Rosa, L. A., Amarowicz, R., \& Sahidi, F. (2010). Antioxidant activity of fresh and processed Jalapeño and Serrano peppers. Journal of Agricultural and Food Chemistry, 59(1), 163-173.

Barroso, E., Van de Wiele, T., Jiménez-Girón, A., Muñoz-González, I., Martín-Álvarez, P., Moreno-Arribas, M., ... Requena, T. (2014). Lactobacillus plantarum IFPL935 impacts colonic metabolism in a simulator of the human gut microbiota during feeding with red wine polyphenols. Applied Microbiology and Biotechnology, 98, 6805-6815.

Bedani, R. (2008). Influencia do consume de "iogurte" de soja fermentado com Enterococcus faecium CRL 183 na microbiota intestinal de animais e humanos. M. S. c. DissertationAraraquara, Sao Paulo, Brasil: Faculdade de Ciencias Farmaceuticas, UNESP140.

Bello-Pérez, L. A., Flores-Silva, P. C., Agama-Acevedo, E., de Dios Figueroa-Cárdenas, J., López-Valenzuela, J. A., \& Campanella, O. H. (2014). Effect of the nixtamalization with calcium carbonate on the indigestible carbohydrate content and starch digestibility of corn tortilla. Journal of Cereal Science, 60, 421-425.

Campos-Vega, R., Reynoso-Camacho, R., Pedraza-Aboytes, G., Acosta-Gallegos, J. A., Guzman-Maldonado, S. H., Paredes-Lopez, O., ... Loarca-Piña, G. (2009). Chemical composition and in vitro polysaccharide fermentation of different beans (Phaseolus vulgaris L.). Journal of Food Science, 74, 59-65.

Carrasco-Castilla, J., Hernández-Álvarez, A. J., Jiménez-Martínez, C., Jacinto-Hernández, C., Alaiz, M., Girón-Calle, J., ... Dávila-Ortiz, G. (2012). Antioxidant and metal chelating activities of Phaseolus vulgaris L. var. Jamapa protein isolates, phaseolin and lectin hydrolysates. Food Chemistry, 131(4), 1157-1164.

Chávez-Mendoza, C., \& Sánchez, E. (2017). Bioactive compounds from Mexican carieties of the common bean (Phaseolus vulgaris): Implications for health. Molecules, 22, 1360.

Daguet, D., Pinheiro, I., Verhelst, A., Possemiers, S., \& Marzorati, M. (2016) Arabinogalactan and fructooligosaccharides improve the gut barrier function in distinct areas of the colon in the simulator of the human intestinal microbial ecosystem. Journal of Functional Foods, 20, 369-379.

De Boever, P., Deplancke, B., \& Verstraete, W. (2000). Fermentation by gut microbiota cultured in a simulator of the human intestinal microbial ecosystem is improved by supplementing a soygerm powder. The Journal of Nutrition, 130, 2599-2606.

Duda-Chodak, A., Tarko, T., Satora, P., \& Sroka, P. (2015). Interaction of dietary compounds, especially polyphenols, with the intestinal microbiota: A review. European Journal of Nutrition, 54, 325-341.

Duque, A. L. R. F., Monteiro, M., Adorno, M. A. T., Sakamoto, I. K., \& Sivieri, K. (2016). An exploratory study on the influence of orange juice on gut microbiota using a dynamic colonic model. Food Research International, 84, 160-169.

Epps, H. M., \& Gale, E. F. (1942). The influence of the presence of glucose during growth on the enzymic activities of Escherichia coli: Comparison of the effect with that produced by fermentation acids. Biochemical Journal, 36, 619-623.

Flint, H. J., Duncan, S. H., Scott, K. P., \& Louis, P. (2015). Links between diet, gut microbiota composition and gut metabolism. Proceedings of the Nutrition Society, 74, $13-22$.

Flores, M., Macias, N., Rivera, M., Lozada, A., Barquera, S., Rivera-Dommarco, J., \& Tucker, K. L. (2010). Dietary patterns in Mexican adults are associated with risk of being overweight or obese. The Journal of Nutrition, 140, 1869-1873.

Gálvez, A., \& Salinas, G. (2015). El papel del frijol en la salud nutrimental de la población mexicana. Revista Digital Universitaria, 16(2), 16

Geirnaert, A., Steyaert, A., Eeckhaut, V., Debruyne, B., Arends, J. B., Van Immerseel, F., \& Van de Wiele, T. (2014). Butyricicoccus pullicaecorum, a butyrate producer with probiotic potential, is intrinsically tolerant to stomach and small intestine conditions. Anaerobe, 30, 70-74.

Goñi, I., Garcia-Diz, L., Mañas, E., \& Saura-Calixto, F. (1996). Analysis of resistant starch: A method for foods and food products. Food Chemistry, 56, 445-449.

González de Mejía, E., Valadez-Vega, M. D. C., Reynoso-Camacho, R., \& Loarca-Piña, G. (2005). Tannins, trypsin inhibitors and lectin cytotoxicity in terapy (Phaseolus acutifolius) and common (Phaseolus vulgaris) beans. Plant Foods for Human Nutrition, 60(3), 137-145.

Guerra, A., Etienne-Mesmin, L., Livrelli, V., Denis, S., Blanquet-Diot, S., \& Alric, M. (2012). Relevance and challenges in modeling human gastric and small intestinal digestion. Trends in Biotechnology, 30(11), 591-600.

Hamer, H. M., Jonkers, D., Venema, K., Vanhoutvin, S., Troost, F. J., \& Brummer, R. J. (2008). Review article: The role of butyrate on colonic function. Alimentary Pharmacology \& Therapeutics, 27, 104-119.

Haralampu, S. G. (2000). Resistant starch- a review of the physical properties and biological impact of RS3. Carbohydrate Polymers, 41, 285-292.

Henningsson, A. M., Nyman, E. M. G. L., \& Bjork, I. M. E. (2002). Short chain fatty acid content in the hindgut of rats fed various composite foods and commercial dietary fiber fractions from similar sources. Journal of the Science of Food and Agriculture, 82, 385-393.

Huda-Faujan, N., Abdulamir, A. S., Fatimah, A. B., Anas, O. M., Shuhaimi, M., Yazid, A. M., \& Loong, Y. Y. (2010). The impact of the level of the intestinal short chain fatty acids in inflammatory bowel disease patients versus healthy subjects. The Open Biochemistry Journal, 4, 53-58.

Hughes, R., Magee, E. A. M., \& Bingham, S. (2000). Protein degradation in the large intestine: Relevance to colorectal cancer. Current Issues in Intestinal Microbiology, 1, $51-58$.

Jakobek, L. (2015). Interactions of polyphenols with carbohydrates, lipids and proteins. Food Chemistry, 175, 556-567.

Jin, J.-S., \& Hattori, M. (2012). Isolation and characterization of a human intestinal bacterium Eggerthella sp. CAT-1 capable of cleaving the ring C-ring of $(+)$-catechin and (-)-epicatechin, followed by p-dehydroxylation of the B-ring. Biological and Pharmaceutical Bulletin, 32(12), 2252-2256.

Kemperman, R. A., Bolca, S., Roger, L. C., \& Vaughan, E. E. (2010). Novel approaches for analysing gut microbes and dietary polyphenols: Challenges and opportunities. Microbiology, 156, 3224-3231.

Kemperman, R. A., Gross, G., Mondot, S., Possemiers, S., Marzorati, M., Van de Wiele, T., \& Vaughan, E. E. (2013). Impact of polyphenols from black tea and red wine/grape juice on a gut model microbiome. Food Research International, 53, 659-669.

Kleiner, D., Traglauer, A., \& Domm, S. (1998). Does ammonia production by Klebsiella contribute to pathogenesis? Bulletin de l'Institut Pasteur, 96, 257-265.

Lee, H. C., Jenner, A. M., Low, C. S., \& Lee, Y. K. (2006). Effect of tea phenolics and their aromatic fecal bacterial metabolites on intestinal microbiota. Research in Microbiology, 157, 876-884.

Louis, P., Scott, K. P., Duncan, S. H., \& Flint, H. J. (2007). Understanding the effects of diet on bacterial metabolism in the large intestine. Journal of Applied Microbiology, 102, 1197-1208.

Macfarlane, G. T., Gibson, G. R., \& Cummings, J. H. (1992). Comparison of fermentation reactions in different regions of the human colon. Journal of Applied Microbiology, 72, 57-64.

Macfarlane, S., \& Macfarlane, G. T. (2003). Regulation of short-chain fatty acid production. Proceedings of the Nutrition Society, 62, 67-72.

Marzorati, M., Maquet, V., \& Possemiers, S. (2017). Fate of chitin-glucan in the human gastrointestinal tract as studied in dynamic gut simulator (SHIME ${ }^{\circledR}$. Journal of Functional Foods, 30, 313-320.

Molly, K., Woestyne, M. V., Smet, I. D., \& Verstraete, W. (1994). Validation of the simulator of the human intestinal microbial ecosystem (SHIME) reactor using microorganism-associated activities. Microbial Ecology in Health and Disease, 7, 191-200.

Molly, K., Woestyne, M. V., \& Verstraete, W. (1993). Development of a 5-step multichamber reactor as a simulation of the human intestinal microbial ecosystem. Applied Microbiology and Biotecnology, 39, 254-258.

Montreau, F. (1972). Sur le dosage des composés phénoliques totaux dans les vins par la methode Folin-Ciocalteau. Connaiss Vigne Vin. Vol. 24. Connaiss Vigne Vin (pp. $397-$ 404).

Munoa, F. J., \& Pares, R. (1988). Selective medium for isolation and enumeration of Bifidobacterium spp. Applied and Environmental Microbiology, 54, 1715-1718.

Nugent, A. (2005). Health properties of resistant starch. Nutrition Bulletin, 30, 27-54.

Payne, S., Gibson, G., Wynne, A., Hudspith, B., Brostoff, J., \& Tuohy, K. (2003). In vitro studies on colonization resistance of the human gut microbiota to Candida albicans and the effects of tetracycline and lactobacillus plantarum LPK. Current Issues in Intestinal Microbiology, 4, 1-8.

Pérez-Jiménez, J., Arranz, S., Taberneo, M., Díaz-Rubio, M. E., Serrano, J., Goñi, I., \& Saura-Calixto, F. (2008). Updated methodology to determine antioxidant capacity in plant foods, oils and beverages: Extraction, measurement and expression of results. Food Research International, 41(3), 274-285.

Possemiers, S., Marzorati, M., Verstraete, W., \& Van de Wiele, T. (2010). Bacteria and chocolate: A successful combination of probiotic delivery. International Journal of Food Microbiology, 141(1), 97-103.

Possemiers, S., Verthé, K., Uyttendaele, S., \& Verstraete, W. (2004). PCR-DGGE-based quantification of stability of microbial community in a simulator of the human in testinal microbial ecosystem. FEMS Microbiology Ecology, 49, 495-507.

Rivera, J. A., Barquera, S., Campirano, F., Campos, I., Safdie, M., \& Tovar, V. (2002). Epidemiological and nutritional transition in Mexico: Rapid increase of non-communicable chronic diseases and obesity. Public Health Nutrition, 5(1a), 113-122.

Rojas-Molina, I., Gutierrez-Cortez, E., Palacios-Fonseca, A., Baños, L., Pons-Hernández, J., Guzmán-Maldonado, S., ... Rodríguez, M. (2007). Study of structural and thermal changes in endosperm of quality protein maize during traditional nixtamalization process. Cereal Chemistry, 84(4), 304-312.

Sanguinetti, C. J., Dias, N. E., \& Simpson, A. J. (1994). Rapid silver staining and recovery of PCR products separated on polyacrylamide gels. BioTechniques, 17, 914-921.

Saura-Calixto, F., García-Alonso, A., Goni, I., \& Bravo, L. (2000). In vitro determination of the indigestible fraction in foods: An alternative to dietary fiber analysis. Journal of Agricultural and Food Chemistry, 48, 3342-3347.

Sáyago-Ayerdi, S. G., Tovar, J., Osorio-Díaz, P., Paredes-López, O., \& Bello-Pérez, L. A. (2005). In vitro starch digestibility and predict glycemic index of corn tortilla, black beans, and tortilla-bean mixture: Effect of cold storage. Journal of Agricultural and Food Chemistry, 53, 1281-1285.

Sáyago-Ayerdi, S. G., Zamora-Gasga, V. M., \& Venema, K. (2017). Prebiotic effect of predigested mango peel on gut microbiota assessed in a dynamic in vitro model of the human colon (TIM-2). Food Research International (In Press).

Scheppach, W., Bartram, H. P., \& Richter, F. (1995). Role of short-chain fatty acids in the prevention of colorectal cancer. European Journal of Cancer, 31, 1077-1080.

Scott, K. P., Gratz, S. W., Sheridan, P. O., Flint, H. J., \& Duncan, S. H. (2013). The influence of diet on the gut microbiota. Pharmacological Research, 69, 52-60.

Silva-Cristobal, L., Osorio-Díaz, P., Tovar, J., \& Bello-Pérez, L. A. (2010). Chemical composition, carbohydrate digestibility, and antioxidant capacity of cooked black bean, chickpea, and lentil Mexican varieties. CyTA Journal of Food, 8, 7-14.

Sivieri, K., Morales, M. L. V., Saad, S. M., Adorno, M. A. T., Sakamoto, I. K., \& Rossi, E. A. (2014). Prebiotic effect of fructooligosacharide in the simulator of the human intestinal microbial ecosystem (SHIME ${ }^{\circledR}$ model). Journal of Medicinal Food, 17 894-901.

Smith, E. A., \& Macfarlane, G. T. (1998). Enumeration of amino acid fermenting bacteria in the human large intestine: Effects of $\mathrm{pH}$ and starch on peptide metabolism and dissimilation of amino acids. FEMS Microbiology Ecology, 25, 355-368.

Topping, D. L. (2007). Cereal complex carbohydrates and their contribution to human health. Journal of Cereal Science, 46, 220-229.

Treviño-Mejía, D., Luna-Vital, D. A., Gaytán-Martínez, M., Mendoza, S., \& Loarca-Piña, G. (2016). Fortification of commercial nixtamalized maize (Zea mays L.) with common bean (Phaseolus vulgaris L.) increased the nutritional and nutraceutical content of tortillas without modifying sensory properties. Journal of Food Quality, 39, 569-579. 
Van De Wiele, T., Boon, N., Possemiers, S., Jacobs, H., \& Verstraete, W. (2007). Inulintype fructans of longer degree of polymerization exert more pronounced in vitro prebiotic effects. Journal of Applied Microbiology, 102, 452-460.

Van De Wiele, T., Boon, N., Possemiers, S., \& Verstraete, W. (2004). Prebiotic effect of chicory inulin in the simulator of the human intestinal microbial ecosystem. FEMS Microbiology, 51, 143-153.

Wolever, T. M., Robb, P. A., Ter Wal, P., \& Spadafora, P. G. (1993). Interaction between methane-producing status and diet on serum acetate concentration in humans. The Journal of Nutrition, 123, 681-688.
Yin, S.-W., Tang, C.-H., Wen, Q.-B., Yang, X.-Q., \& Yuan, D.-B. (2010). The relationships between physicochemical properties and conformational features of succinylated and acetylated kidney bean (Phaseolus vulgaris L.) protein isolates. Food Research International, 43(3), 730-780.

Zamora-Gasga, V. M., Álvarez-Vidal, C., Montalvo-González, E., Loarca-Piña, G., VázquezLandaverde, P. A., Bello-Pérez, L. A., ... Sáyago-Ayerdo, S. G. (2018). Gut metabolites associated with $\mathrm{pH}$ and antioxidant capacity during in vitro colonic fermentation of Mexican corn products. Cereal Chemistry, 95(3), 399-410. 